\title{
STANOWISKO UNII EUROPEJSKIEJ WOBEC NOWEJ AGENDY ROZWOJOWEJ POST 2015
}

Ważność aktualnej, globalnej agendy rozwojowej, znanej pod nazwą Milenijne Cele Rozwoju (ang. Millenium Development Goals, dalej: MDGs), kończy się 31 grudnia 2015 r. Od 2010 r. trwają prace analityczne, programowe nad nową agendą rozwojową, która zastapi MDGs począwszy od 1 stycznia 2016 r. Unia Europejska jest bardzo aktywnym uczestnikiem prac nad kształtem kolejnej agendy rozwojowej. Aktywność UE w tym obszarze wynika zarówno z ambicji tej organizacji, chcącej odgrywać rolę „globalnego gracza”, jak i znaczenia założeń globalnej polityki rozwojowej dla unijnej współpracy rozwojowej. Unijna współpraca rozwojowa jest bardzo ściśle związana z globalną agendą rozwojową. Art. 208 ust. 3 Traktatu o funkcjonowaniu Unii Europejskiej stanowi: „Unia i Państwa Członkowskie szanują zobowiązania i uwzględniają cele, na które wyraziły zgodę w ramach Organizacji Narodów Zjednoczonych i innych właściwych organizacji międzynarodowych" (Traktat, 2007: art. 208.3). Rozdział traktatu zatytułowany „Współpraca na rzecz rozwoju” kończy art. 211, który brzmi: „W zakresie swoich odpowiednich kompetencji Unia i Państwa Członkowskie współpracują z państwami trzecimi i właściwymi organizacjami międzynarodowymi” (ibidem: art. 211).

Unia Europejska ogłosiła rok 2015 Europejskim Rokiem na rzecz Rozwoju (ang. European Year for Development, dalej: EYD). Była to propozycja Komisji Europejskiej, zatwierdzona przez Parlament Europejski i Radę Europejską (Rezolucja, 2014). Motto tej inicjatywy to hasło: „Nasz świat, nasza godność, nasza przyszłość”. Z perspektywy polityki zagranicznej istotne jest to, że po raz pierwszy w historii wszystkich 23 , kolejnych ,europejskich lat”, tematem przewodnim ,europejskiego roku” jest zewnętrzna działalność UE. Inauguracja tej inicjatywy odbyła się 9 stycznia 2015 r. w Rydze ${ }^{1}$.

Jedną z podstawowych przyczyn podjęcia tej inicjatywy był fakt, że rok 2015 będzie rokiem, w którym powinny zapaść decyzje w ramach ONZ o globalnych celach współpracy rozwojowej, które będą realizowane po roku 2015. We wrześniu 2015 r. podczas Zgromadzenia Ogólnego ONZ powinna zostać podpisana przez przywódców państw członkowskich i ogłoszona nowa globalna agenda rozwojowa (dalej: Post 2015). Będzie ona następcą Milenijnych Celów Rozwojowych, przyjętych w roku 2000 i ukształtuje współpracę rozwojową na kolejne 15 lat. Dla wszystkich środowisk, organizacji, instytucji zajmujących się współpracą rozwojową będzie to kluczowy dokument programowy. Rezolucja Parlamentu Europejskiego, wprowadzająca EYD, stwierdza

${ }^{1}$ Koordynatorem Europejskiego Roku na rzecz Rozwoju w Polsce jest Ministerstwo Spraw Zagranicznych. 
m.in.: „Rok 2015 powinien stać się rokiem symbolicznym i przełomowym, jako ostatni rok realizacji wspólnie uzgodnionych milenijnych celów rozwoju, a przez to będzie stanowił unikalną szansę oceny stanu realizacji zobowiązań międzynarodowych. Również w roku 2015 mają zostać podjęte na poziomie międzynarodowym istotne decyzje co do ram rozwoju, które w kolejnych dekadach zastąpią milenijne cele rozwoju". Celem tej inicjatywy jest m.in.: ,informowanie obywateli Unii o współpracy Unii i państw członkowskich na rzecz rozwoju, podkreślając rezultaty, jakie Unia we współdziałaniu z państwami członkowskimi osiagnęła na arenie międzynarodowej i będzie nadal osiagać w myśl ostatnich dyskusji na temat nadrzędnego programu działań na okres po roku 2015" (ibidem).

Wszystkie kluczowe instytucje UE pracują nad unijnym stanowiskiem wobec wyzwania, jakie stanowi konieczność ustalenia nowej agendy rozwojowej. UE i jej przedstawiciele próbują również oddziaływać na stanowisko innych podmiotów uczestniczących w tych pracach. Sześcioro Europejczyków brało udział w pracach High-Level Panel of Eminent Persons on the Post-2015 Development Agenda (HLP), powołanym przez sekretarza generalnego ONZ. Współprzewodniczącym tego gremium był David Cameron (Wielka Brytania, premier), a w jego skład weszli: Gunilla Clarsson (Szwecja, minister ds. międzynarodowej współpracy i rozwoju), Andris Piebalgs (Łotwa, komisarz ds. współpracy rozwojowej UE), Horst Köhler (Niemcy, były prezydent), Paul Polman (Holandia, prezes firmy Unilever) i Jean-Michele Severino (Francja, były dyrektor Agence Française de Développement). High-Level Panel ogłosił swój końcowy raport w roku 2013 (A New Global, 2013).

Komisja Europejska przyjęła cztery komunikaty, dotyczące nowej agendy:

- „Godne życie dla wszystkich: eliminacja ubóstwa i zapewnienie światu zrównoważonej przyszłości” (27 lutego 2013 r.);

- „Perspektywy po roku 2015: w stronę wszechstronnego i zintegrowanego podejścia do finansowania eliminacji ubóstwa i do zrównoważonego rozwoju" (16 lipca 2013 r.);

- „Większa rola sektora prywatnego w osiaganiu trwałego wzrostu gospodarczego sprzyjającego włączeniu społecznemu w krajach rozwijających się" (13 maja 2014 r.);

- „Godne życie dla wszystkich: od wizji do wspólnego działania” (2 czerwca 2014 r.).

Komisja Europejska opublikowała również dokument zatytułowany „W kierunku ustanowienia ram rozwoju po 2015", będący wynikiem konsultacji społecznych w sprawie przygotowania stanowiska UE, które przeprowadzono w dniach od 15 czerwca do 15 września 2012 r. W konsultacjach, polegających na wypełnieniu specjalnego kwestionariusza, uczestniczyło 119 instytucji i osób, ale trudno uznać je za reprezentatywne dla całej UE. Aż 51 odpowiedzi pochodziło bowiem z Belgii, 18 z Wielkiej Brytanii, 7 z Niemiec, 5 z Holandii, po 3 z Austrii, Finlandii i Włoch, po 2 z Irlandii, Francji i Hiszpanii i po 1 z 6 innych państw UE (w tym z Polski). Pozostałych 17 odpowiedzi pochodziło spoza UE (Nikaragua, Mali, USA, Kanada, Mauritius, Benin, Kambodża, Urugwaj, Malezja, Wenezuela, Tanzania i Togo).

Osobą odpowiedzialną za prace Komisji Europejskiej nad nową agendą jest obecnie komisarz ds. współpracy międzynarodowej i rozwoju Neven Mimica. Kwestia nowej agendy rozwojowej w hierarchii spraw, które zajmują komisarza, plasuje się wysoko. W swoim pierwszym wystąpieniu, podczas przesłuchania przed Komisją Rozwoju Parlamentu Europejskiego, 29 września 2014 r. komisarz uznał przyjęcie ambitnych ram 
nowej agendy rozwojowej za swój pierwszy priorytet. Powtórzył to zresztą 24 listopada podczas debaty nad nową agendą rozwojową w Parlamencie Europejskim i 16 lutego 2015 r.: ,to absolutnie jasne, że ambitna agenda rozwojowa Post 2015 jest moim najwyższym priorytetem" (Commission, 2015).

Parlament Europejski przyjął dwa raporty i dwa zalecenia w tej sprawie ${ }^{2}$, zaś Rada czterokrotnie przyjmowała konkluzje z obrad, podczas których dyskutowano o nowej agendzie rozwojowej ${ }^{3}$.

Kwestią nowej agendy rozwojowej zajmowały się również organy doradcze UE. Europejski Komitet Ekonomiczno-Społeczny przyjął między innymi opinię pt. „Ustanowienie celów zrównoważonego rozwoju: wkład społeczeństwa obywatelskiego w stanowisko UE” (18 września 2013 r.) i opinię pt. „Zaangażowanie sektora prywatnego w ramy rozwoju na okres po 2015 r.” (16 października 2013 r.). Komitet Regionów na sesji 9 października 2013 r. przyjął z kolei opinię pt.: „Empowering local authorities in partner countries for enhanced governance and more effective development outcomes".

Bardzo aktywne w pracach nad nową agendą rozwojową są europejskie organizacje pozarządowe, zajmujące się współpracą rozwojową. Za najbardziej reprezentatywny dla tego środowiska należy uznać dokument pt.: „Putting People and Planet First. CONCORD - Beyond 2015 European Task Force Recommendations for the Post-2015 Framework" (2013). CONCORD to Europejska Konfederacja Organizacji Pozarzadowych na rzecz Pomocy $i$ Rozwoju. Rekomendacje przygotował specjalnie powołany do tego zespół zadaniowy, którego komitet sterujący, składał się z przedstawicieli 11 organizacji ${ }^{4}$. Opinia CONCORD ma znaczenie dla stanowiska UE, gdyż konfederacja ta zrzesza 1800 europejskich organizacji pozarządowych i jako jedyna uzyskała możliwość ,strukturalnego dialogu” z Komisja Rozwoju Parlamentu Europejskiego. Prace zespołu zadaniowego, powołanego przez CONCORD były rzeczywiście szerokie. W pierwszej fazie 56 organizacji zgłosiło ponad 800 uwag i komentarzy, w drugiej fazie 40 organizacji przesłało 482 uwagi. Zasięg prac nad stanowiskiem organizacji pozarządowych był znacznie szerszy niż oficjalne konsultacje Komisji Europejskiej, gdyż nie ograniczał się do udzielenia odpowiedzi na pytania z przygotowanego wcześniej kwestionariusza. Efektem prac redakcyjnych i programowych zespołu zadaniowego

2 1) Sprawozdanie z 13 czerwca 2013 r. w sprawie milenijnych celów rozwoju - określenie ram po 2015 r. (autor niniejszego artykułu był sprawozdawcą tego raportu); 2) Zalecenie Parlamentu Europejskiego dla Rady z 11 czerwca 2013 r. w sprawie 68. sesji Zgromadzenia Ogólnego Organizacji Narodów Zjednoczonych; 3) Zalecenie Parlamentu Europejskiego dla Rady z 2 kwietnia 2014 r. w sprawie 69. sesji Zgromadzenia Ogólnego Organizacji Narodów Zjednoczonych; 4) Sprawozdanie w sprawie UE i globalnych ram rozwoju po roku 2015 (25 listopada 2014 r.).

${ }_{3}$ Chodzi o: konkluzje Rady do Spraw Ogólnych z 25 czerwca 2013 r. w sprawie nadrzędnego programu działań na okres po roku 2015; konkluzje Rady do Spraw Zagranicznych z 12 grudnia 2013 r. w sprawie finansowania eliminacji ubóstwa i zrównoważonego rozwoju po 2015 r.; konkluzje Rady do Spraw Zagranicznych z 19 maja 2014 r. w sprawie podejścia do współpracy na rzecz rozwoju, opartego na prawach i obejmującego wszystkie prawa człowieka; konkluzje Rady do Spraw Ogólnych z 16 grudnia 2014 r. w sprawie transformacyjnej agendy po roku 2015.

${ }_{4}^{4}$ 11.11.11, Caritas Europa, Cidse, CONCORD Denmark, CYINDEP, HelpAge International, Kehys, Plan International, Save the Children, Trocaire, WWF. 
CONCORD jest 42-stronnicowy dokument, którego hasłem przewodnim jest stwierdzenie: „Business as usual is not an option”.

Komisja Europejska zamówiła też dwa obszerne raporty, przygotowane przez konsorcjum niezależnych instytutów ${ }^{5}$. Pierwszy - „European Report on Development. Post 2015: Global Action for an Inclusive and Sustainable Future” (European, 2013) został opublikowany. Nad drugim, noszącym tytuł - „Financing and other means of implementation in the post-2015 context" prace jeszcze trwają ${ }^{6}$. Istotnym walorem pierwszego raportu jest jego ostatni rozdział, zawierający krytyczne konkluzje i rekomendacje. Autorzy raportu szczerze, moim zdaniem, przewidują na przykład, że w perspektywie średnioterminowej poziom oficjalnej pomocy rozwojowej (ODA) państw UE będzie w stagnacji. Podkreślają też, że mimo wysiłków w sprawie spójności polityk na rzecz rozwoju (PCD) niż inni donatorzy, efekty tychże wysiłków są „ograniczone”. I to nawet w tych dziedzinach, w których negatywny wpływ na kraje rozwijające się jest najbardziej widoczny. UE od dawna ma problem w pogodzeniu własnych interesów wewnętrznych $\mathrm{w}$ rolnictwie i w rybołówstwie z interesami krajów rozwijających się (ibidem: 223).

Choć raport wymienia też mocne strony współpracy rozwojowej UE, ale ciekawsze są uwagi krytyczne, gdyż w dokumentach instytucji unijnych pojawiają się one dość rzadko. Intencją jest wskazanie obszarów, w których sama UE może polepszyć swe działania w kontekście nowej agendy rozwojowej. Raport wskazuje na utrzymywanie taryfowych i poza-taryfowych barier handlowych, ograniczoną elastyczność UE w negocjacjach, dotyczących umów o partnerstwie gospodarczym (ang. EPAs), brak przejrzystości w niektórych inwestycjach bezpośrednich (przemysł wydobywczy), słaby postęp w ograniczaniu nielegalnych przepływów finansowych (praniu „brudnych” pieniędzy), fragmentowanie systemu unijnej pomocy rozwojowej, które obniża jej skuteczność, restrykcyjne polityki narodowe w zakresie imigracji, opór państw członkowskich wobec zmian w legislacji migracyjnej UE oraz niezdolność do umożliwienia prawdziwego postępu w negocjacjach, dotyczących zasad światowego handlu (ibidem: 224).

Mnogość dokumentów unijnych instytucji, dotyczących nowej agendy rozwojowej nie ułatwia zdiagnozowania rzeczywistych priorytetów UE w debacie nad globalnymi ramami współpracy rozwojowej. Nie udało się również uniknąć swoistego „koncertu życzeń" w formułowaniu potencjalnych celów rozwojowych po roku 2015. Wielu ekspertów przestrzegało przed tym zagrożeniem, m.in. autorzy wskazanego powyżej raportu z 2013 r. Pisali oni: „Ważne jest by agenda po roku 2015 nie była przeładowana długą listą życzeniowych celów, próbujących uwzględnić wszystkie możliwe aspekty inkluzywnego i zrównoważonego rozwoju" (ibidem: 217). W najnowszym komunikacie Komisji, dotyczącym przyszłej agendy „Godne życie dla wszystkich: od wizji do wspólnego działania” potencjalnych celów rozwojowych sformułowano aż 77 . Warto

5 European Centre for Development Policy Management, German Development Institute, Overseas Development Institute.

${ }^{6}$ Do konsorcjum dołączyły w tym przypadku dwie dodatkowe instytucje: University of Athens (Department of Economics, Division of International Economics and Development) i Southern Voice Network. 
jednak dodać, że nie odbiega to znacząco od metody pracy innych instytucji. Organy ONZ, w których odbywają się kluczowe, dla agendy Post 2015, prace również formułują znaczącą liczbę potencjalnych celów. Propozycje The Open Working Group for Sustainable Development Goals, które są podstawą negocjacji międzyrządowych państw członkowskich ONZ, zawierają 17 podstawowych celów i 169 celów szczegółowych (Proposal, 2014).

Jednocześnie rola UE $\mathrm{w}$ procesie ustanawiania nowej agendy rozwojowej jest wyjątkowa. Wynika to m.in. z faktu, że żaden inny dawca pomocy w obszarze współpracy wielostronnej nie ma takich środków i możliwości, jak UE (Re-Shaping, 2014: 3). Inne podmioty, jak na przykład grupa Banku Światowego mają wprawdzie pieniądze, ale nie mają wpływu na zasady handlu światowego, ani tytułu do wypowiadania się w kwestiach praw człowieka, polityki zagranicznej czy polityki bezpieczeństwa. ONZ ma z kolei znaczenie normatywne i polityczne, ale nie ma zdolności do wypłacania pomocy w takiej samej skali czy przy pomocy tylu instrumentów, co UE. Poza tym Unia deklaruje polityczne zainteresowanie procesem negocjacji, ma duży potencjał negocjacyjny i chciałaby, aby nowa agenda rozwojowa była ambitna. O zaangażowaniu tym świadczy chociażby fakt, iż w czasie specjalnego wydarzenia ONZ „Towards achieving the Millenium Development Goals”, we wrześniu 2013 r. do Nowego Jorku przybyło 12 różnych delegacji Unii Europejskiej (nie licząc przedstawicieli państw członkowskich). Wśród nich przewodniczący Komisji Europejskiej, przewodniczący Rady Europejskiej, Wysoka Przedstawiciel Unii do Spraw Zagranicznych i Polityki Bezpieczeństwa, siedmiu komisarzy (z których każdy stanowił odrębną delegację), delegacja Parlamentu Europejskiego oraz delegacja Europejskiego Komitetu Społeczno-Ekonomicznego.

Punktem wyjścia unijnych rozważań o możliwych celach nowej agendy rozwojowej jest stwierdzenie: „Sednem unijnej wizji jest to, że świat dysponuje technologiami i zasobami umożliwiającymi eliminację skrajnego ubóstwa za naszego życia i ukierunkowanie świata na ścieżkę zrównoważonego rozwoju, aby zapewnić wszystkim godne życie do 2030 r." (Godne, 2014: 3). Jednocześnie instytucje unijne dostrzegają bardzo długą listę problemów współczesnego świata: „...łamanie praw człowieka, nierówności, w tym nierówności między płciami, konflikty zbrojne i terroryzm, zmiana klimatu, brak bezpieczeństwa żywnościowego, brak praw własności, brak praw do gruntów, migracja, ograniczony dostęp do usług w zakresie opieki zdrowotnej i edukacji, zmiany demograficzne, ograniczone zasoby, utrata bioróżnorodności, korupcja, oszustwa podatkowe i uchylanie się od płacenia podatków, niestabilny wzrost, bezrobocie oraz kryzysy finansowe i gospodarcze" (Sprawozdanie, 2014: 9). Niestety wszystkie te kwestie są uznawane za „kluczowe”, co powoduje, że rzeczywiste priorytety UE w tym zakresie nie są jednoznacznie sformułowane.

Komisja Europejska stawia też przyszłym ramom rozwojowym określone i ambitne wymagania metodologiczne. Ramy te powinny być globalne (w zakresie swego zasięgu), uniwersalne, powinny opierać się na odpowiedzialności każdego z państw, opierać się na prawach, być dopasowane do lokalnych warunków (uwzględniać różne krajowe konteksty i poziomy rozwoju), nakierowane na ludzi i ich potrzeby, uznawać powiązania między eliminacją ubóstwa i zrównoważonym rozwojem, łączyć w sobie trzy wymiary zrównoważonego rozwoju (społeczny, środowiskowy i gospodarczy), możliwe 
do rozliczenia, przejrzyste i umożliwiające efektywny przegląd postępów (Godne, 2014: 3-4).

Komisja Europejska chciałaby również, aby cele szczegółowe były: „skonkretyzowane, mierzalne, osiagalne, adekwatne i do realizacji w określonym czasie (ang. specific, measurable, achievable, relevant and time-bound, tj. cele SMART). Powinny opierać się na dowodach i dostępnych danych..." (ibidem: 13). Podejście Parlamentu Europejskiego jest jeszcze bardziej wymagające. Nowa agenda rozwojowa, w opinii posłów, powinna:

- odzwierciedlać wyzwania globalne, regionalne, krajowe i lokalne;

- wiązać się ze współodpowiedzialnością (również państw o średnim dochodzie i krajów rozwijających się);

- równo i sprawiedliwie dzielić obowiązki i obciążenia między wszystkie państwa;

- być ambitna, powszechna, globalna, wielowymiarowa i elastyczna;

- obejmować cele dostosowane do poszczególnych krajów, charakteryzujące się prostotą, precyzją, ukierunkowaniem na działanie, łatwością ich komunikowania, dostosowaniem do realiów lokalnych, krajowych i regionalnych;

- zawierać ograniczoną liczbę konkretnych i mierzalnych celów;

- przestrzegać zasad odpowiedzialności, rozliczania, przejrzystości, demokracji, praw człowieka, dobrego sprawowania rządów, praworządności, pokoju i bezpieczeństwa, równości i sprawiedliwości oraz równości płci;

- łączyć wymiar ekonomiczny, społeczny i środowiskowy zrównoważonego rozwoju;

- zmobilizować wszystkie możliwe zasoby finansowe oraz innowacyjne mechanizmy finansowania rozwoju;

- uwzględniać partnerów spoza szczebla rządu krajowego;

- uwzględniać spójność polityki na rzecz rozwoju (Sprawozdanie, 2013: 21-22).

Założenia metodologiczne UE, przyjęte jako wytyczne do formułowania potencjalnych celów nowej agendy rozwojowej, budzą poważne dyskusje w niektórych państwach rozwijających się. W wymiarze globalnym nie ma bowiem powszechnej zgody, co do tego, które wartości i zasady mają charakter w pełni uniwersalny. Najwięcej różnic można zaobserwować $\mathrm{w}$ interpretacji uniwersalnego charakteru niektórych $\mathrm{z}$ praw człowieka (kwestia stosunku do kary śmierci) czy zasad demokracji i równości (w tym równości płci). Podejście instytucji UE jest bardzo jednoznaczne. Parlament Europejski: „podkreśla powszechność, niepodzielność i współzależność wszystkich praw człowieka wszystkich ludzi bez żadnej dyskryminacji, począwszy od podstawowego prawa wszystkich ludzi do godności, przy czym szczególną uwagę należy zwrócić na prawa człowieka kobiet i dziewcząt, $w$ tym promowanie powszechnego dostępu do praw reprodukcyjnych i seksualnych oraz zdrowia reprodukcyjnego i seksualnego oraz ochronę i poszanowanie praw imigrantów i mniejszości, w tym osób LGBTI i osób zakażonych wirusem HIV; podkreśla, jak istotne jest przestrzeganie i promowanie w nowych ramach praw osób niepełnosprawnych" (Sprawozdanie, 2014: 12-13).

Tymczasem z moich obserwacji prac Wspólnego Zgromadzenia Parlamentarnego $A K P-U E$ wynika, że niektóre państwa rozwijające się z grupy państw AKP odbierają unijny nacisk na przestrzeganie praw człowieka jako przejaw aksjologicznego neokolonializmu. John Tomlison opisał nieco szersze zjawisko, które nazwał imperializmem kulturowym. Definiował je jako „stosowanie przewagi politycznej lub ekonomicznej, 
by podnosić i szerzyć wartości i obyczaje kultury obcej kosztem kultury rodzimej" (Tomlison, 1991: 3). Część przedstawicieli AKP nie chce na przykład uznawać europejskiej Karty Praw Podstawowych jako dokumentu odzwierciedlającego prawa powszechne i uniwersalne. Odwołują się, przy tym, do zasad promowanych jednocześnie przez samą UE - zasady własności, zasady współodpowiedzialności i zasady partnerstwa. Chcieliby utrzymać możliwość orzekania i stosowania kary śmierci. Powołują się w tym przypadku na Stany Zjednoczone. W kilku państwach afrykańskich istnieje też stosunkowo silny opór przeciw legalizacji aktów homoseksualnych.

Różnice w podejściu do założeń, będących podstawą określania nowych celów rozwojowych, utrudniają zrealizowanie innego celu UE. Jest nim próba budowania wspólnego stanowiska wobec nowej agendy rozwojowej, łączącego Unię Europejską i Unię Afrykańska. Unia Afrykańska na szczycie w styczniu 2014 r. przyjęła wspólne stanowisko Common African Position (CAP) on the Post-2015 Development Agenda. Z kolei w kwietniu 2014 r. na czwartym szczycie Afryka-UE w Brukseli obie strony zdeklarowały, że są zainteresowane współpraca, której celem jest doprowadzenie do przyjęcia ambitnej i zorientowanej na działanie, agendy Post-2015 (Fourth, 2014). Jednocześnie państwa afrykańskie nie ukrywają że celem negocjacji z ich strony jest „kolektywna własność [ownership] nowej agendy" (Common African, 2014: 4). Liderzy afrykańscy we wspólnym stanowisku nie używają terminu ,prawa człowieka” tylko „podstawowe prawa”, na dodatek w połączeniu ,podstawowe prawa i obowiązki obywateli" (ibidem: 10). Nie można zatem mówić o wspólnym stanowisku UE i UA w zakresie znaczenia praw człowieka dla rozwoju.

Dokumentem unijnym, ważnym dla określenia stanowiska UE wobec nowej agendy rozwojowej jest komunikat KE z czerwca 2014 r. Dokumenty Parlamentu Europejskiego są bardzo ciekawe, ale mniej istotne, gdyż przedstawiciele Parlamentu nie uczestniczą w pracach programowych na poziomie ONZ. Z drugiej strony Rada reprezentuje państwa członkowskie UE, które na poziomie negocjacji międzyrządowych ONZ mają własnych reprezentantów i kierują się oni, przede wszystkim, mandatem otrzymanym od swych rządów narodowych. Powinien on być zgodny ze wspólnym stanowiskiem UE. Konkluzje Rady w sprawie nowej agendy rozwojowej są jednak znacznie bardziej ogólne niż komunikaty Komisji Europejskiej. W konsekwencji to KE odgrywa rolę koordynatora prac unijnych, związanych $\mathrm{z}$ nową agendą rozwojową.

Druga część komunikatu zatytułowana „Potencjalne cele i obszary priorytetowe” rozpoczyna się od, można powiedzieć, klasycznego we współpracy rozwojowej problemu, a mianowicie od ubóstwa. Komisja jednoznacznie zaproponowała kontynuowanie zadania rozpoczętego w roku 2000 przez MDGs. Pierwszym wymienionym celem jest bowiem eliminacja skrajnego ubóstwa. Cele szczegółowe to:

- ograniczenie odsetka osób zagrożonych skrajnym ubóstwem i żyjących za mniej niż 2 dolary dziennie;

- zwiększenie odsetka ludzi żyjących poniżej krajowej granicy ubóstwa;

- ograniczenie kosztów przekazów pieniężnych i ograniczenie kosztów migracji;

- zabezpieczenie praw do ziemi, mienia i innych aktywów;

- zwiększenie odporności i ograniczenie liczby zgonów i strat gospodarczych na skutek klęsk żywiołowych (Godne, 2014: 6). 
Wyeliminowanie skrajnego ubóstwa jest zgodne z priorytetami innych unijnych instytucji. Rada w swych konkluzjach z czerwca 2013 r. stwierdziła, że nowa agenda powinna: ,przyczyniać się do trwałego rozwoju w celu eliminowania ubóstwa we wszystkich jego wymiarach, w tym eliminowania skrajnego ubóstwa w ciągu jednego pokolenia, oraz w celu zapewnienia trwałego dobrobytu i dobrostanu wszystkich ludzi na całym świecie". Raport Parlamentu Europejskiego, przyjęty w listopadzie 2014 r. „przypomina, że likwidacja ubóstwa musi pozostać najważniejszym priorytetem globalnego programu działań na rzecz rozwoju po roku 2015" (Sprawozdanie, 2014: 11). Jest to również zgodne z celami Unii Afrykańskiej, która w swoim stanowisku stwierdziła, że „eliminacja ubóstwa we wszystkich jego formach musi być nadrzędnym priorytetem agendy rozwojowej po roku 2015" (Common African, 2014).

Kolejnym obszarem zainteresowania Komisji jest kwestia nierówności. Zadanie, które stawia KE jest niezwykle ambitne, być możne nawet niewykonalne: „Należy rozwiązać problem nierówności dochodów i różnic majątkowych" (Godne, 2014: 6). Komisja chciałaby też, aby „korzyści płynące ze wzrostu i rozwoju powinny być powszechnie dzielone z korzyścią dla wszystkich członków społeczeństwa" (ibidem). Osiagnięcie tak idealistycznie opisanego celu może być bardzo trudne do zrealizowania. Równie trudne będzie zrealizowanie zaproponowanych celów szczegółowych, tj. zapewnienia, by grupy z niższymi dochodami czerpały takie same korzyści ze wzrostu dochodu narodowego, jak grupy z wyższymi dochodami; oraz wyeliminowania dyskryminacji i nierówności w świadczeniu usług publicznych i w życiu gospodarczym (ibidem). Najbardziej realistyczny w tej grupie celów jest ostatni cel szczegółowy: „wzmocnienie pozycji i włączenie grup zmarginalizowanych, w tym mniejszości etnicznych, imigrantów i uchodźców".

Skłonność do idealistycznego podejścia jest widoczna również w innych obszarach problemowych, proponowanych przez Komisję Europejską. Jedną z najbardziej radykalnych jest propozycja dotycząca służby zdrowia. KE proponuje między innymi dwa cele, których osiagnięcie byłoby trudne nawet w państwach najbardziej rozwiniętych: 1) zapewnienie efektywnego, sprawiedliwego i powszechnego dostępu do wysokiej jakości usług zdrowotnych dla wszystkich; oraz 2) zadbanie o to, aby nikt nie popadł w skrajne ubóstwo lub nie mógł się z niego wydobyć z powodu wydatków na opiekę zdrowotną (ibidem: 7).

W innych dziedzinach cele szczegółowe są określone w sposób realistyczny, ale nazwa całego zadania każe wattpić czy uda się je zrealizować. Jest tak w przypadku działu pt. „Pełne i produktywne zatrudnienie i godna praca dla wszystkich”. Można wątpić, by do roku 2030 było możliwe zapewnienie pełnego, produktywnego i godnego zatrudnienia wszystkim ludziom. Niemniej cele szczegółowe w tym obszarze mają być osiaggalne przez:

- zwiększenie liczby godnych miejsc pracy i zwiększenie zakresu zrównoważonych środków do życia, w tym dla młodzieży, osób starszych, kobiet i grup zagrożonych dyskryminacja;

- zwiększenie udziału produktywnego zatrudnienia i godnej pracy w łącznym zatrudnieniu;

- zwiększenie zakresu objęcia podstawową ochroną socjalną i stopniowe wdrażanie wyższych standardów gwarancji socjalnych; 
- ochrona praw pracowników będących imigrantami oraz przesiedleńców zgodnie z normami i standardami MOP (ibidem: 9).

Unia Europejska świadomie formułuje ambitne propozycje rozwojowe, licząc się z naturalną konsekwencją negocjacji wielostronnych i nieuchronną redukcją zamierzeń, na które mogą zgodzić się wszyscy. Rada też uważa, że potrzebujemy „ambitnej agendy, która nikogo nie zostawi z tyłu" (Konkluzje Rady, 2014b). Podobna taktyka była stosowana w przypadku negocjacji, dotyczących zmian klimatycznych. Warto zauważyć, że sukcesy negocjacyjne UE w kwestiach klimatycznych na poziomie globalnym są, delikatnie mówiąc, umiarkowane.

Trzecią grupą celów, proponowanych przez Komisję Europejską jest blok spraw związanych z bezpieczeństwem żywnościowym i żywieniem oraz zrównoważonym rolnictwem. Co interesujące, dokładnie na trzecim miejscu pojawia się ten cel w stanowisku europejskich organizacji pozarządowych, oczekujących zapewnienia: „Odpowiedniego jedzenia i odżywczej diety dla wszystkich poprzez sprawiedliwy i zrównoważony systemy produkcji żywności” (Putting People, 2013: 8). Komisja preferuje „drobnych producentów rolnych”, którym powinno zapewnić się dostęp do „ziemi, zasobów, inwestycji i rynków" (Godne, 2014: 6). O tym, jak trudne do wykonania jest to zadanie, świadczy fakt, że wpływ Komisji Europejskiej oraz samego ONZ na zapewnienie dostępności pierwszych trzech z tych walorów jest bardzo ograniczony. Jedynie wpływ UE na dostęp do rynków pozostaje względnie znaczny.

Najnowszym dokumentem UE, dotyczącym nowej agendy rozwojowej są konkluzje Rady do Spraw Ogólnych z 16 grudnia 2014 r. w sprawie transformacyjnej agendy po roku 2015. Rada, w imieniu UE i państw członkowskich, zadeklarowała swe poparcie dla połączenia celów rozwojowych i środowiskowych w jedną wspólną agendę. Nowa agenda powinna być odpowiedzią wspólnoty międzynarodowej na ,strukturalne przyczyny ubóstwa, nierówności, zmian klimatycznych i degradacji środowiska naturalnego" (Konkluzje Rady, 2014). Rada powótrzyła też wiodące hasło europejskich organizacji pozarządowych: „Business as usual is no longer an option” (ibidem: 3). Dotyczy ono trzech konkretnych wymiarów: ludzkiej godności, nierówności i zrównoważenia. Powtarzanie hasła organizacji pozarządowych jest zabiegiem populistycznym, gdyż organizacje te oczekują od rządów nie tyle werbalnej zgody z własnymi postulatami, tylko konkretnych działań, zmieniających rzeczywistość.

Rada w swych konkluzjach powtórzyła bardzo długą listę potencjalnych celów rozwojowych. Sposobem na specyficzną integrację tej rozbudowanej agendy ma być wzmocnienie ,synergii, spójności i wzajemnych powiązań”. Za istotny uznano problem spójności polityk na rzecz rozwoju. W praktyce oznacza to, że nowa agenda rozwojowa powinna doprowadzić do zmian zarówno w politykach unijnych, jak i w politykach narodowych państw członkowskich UE. Strategia Zrównoważonego Rozwoju UE czy Strategia Europa 2020 i inne strategie powinny być dostosowane do celów nowej agendy rozwojowej. Rada wymieniła też obszary szczególnie istotne dla spójności polityk na rzecz zrównoważonego rozwoju. Są to: handel, nauka, migracja, technologia i innowacje, wiedza i dostęp do niej (ibidem: 5).

Pozytywnie zareagowano na postulat organizacji pozarządowych w sprawie sposobów mierzenia osiagnięć poszczególnych państw czy grup ludności. Do tej pory, podstawowym miernikiem rozwoju państw pozostawał wskaźnik PKB. Najczęściej 
w przeliczeniu na osobę. Organizacje pozarządowe krytycznie podchodziły do tej praktyki, zwracając uwagę, że PKB „uwzględnia tylko wartość monetarną uznanych towarów i usług", a nie bierze pod uwage ,wykorzystania zasobów naturalnych i tworzenia zanieczyszczeń" (Putting people, 2013: 15-16). Nie uznawały tego wskaźnika jako wystarczającego miernika rozwoju, gdyż w ich opinii, nie odzwierciedla on jakości życia, stopnia dobrobytu, równomierności efektów. Niemniej w argumentacji przeciw stosowaniu miernika PKB pojawiły się również wątki ideologiczne. Jednym z podnoszonych zarzutów jest to, że wskaźnik ten ,przyczynia się do rozprzestrzeniania się modelu kultury konsumpcyjnej, opierającej się na nabywaniu dóbr materialnych" (ibidem: 16). Rada ustapiła nieco organizacjom pozarządowym i przyznała, iż „musimy uznać potrzebę spojrzenia poza PKB na rzecz szerszych mierników postępu, uwzględniających kapitał społeczny, ludzki i naturalny" (Konkluzje Rady, 2014: 6). Podobne stanowisko przyjął też Parlament Europejski, który zaapelował „o szerszą definicję ubóstwa, która nie opierałaby się jedynie na PKB, lecz obejmowała również inne wskaźniki postępu i dobrostanu" (Sprawozdanie, 2014: 12).

Potencjalnym źródłem sporów ideologicznych jest również zapis konkluzji Rady, dotyczący „sexual and reproductive health and rights”. Zakres ,praw reprodukcyjnych" jest różnie interpretowany. Między państwami ONZ nie ma powszechnej zgody, co do ich stosowania. Na przykład Komisja Praw Kobiet i Równouprawnienia Parlamentu Europejskiego jest zwolennikiem szerokiej interpretacji i ,ubolewa, że ciała kobiet i dziewcząt, zwłaszcza ich prawa i zdrowie reprodukcyjne i seksualne, nadal pozostają ideologicznym polem walki, oraz apeluje, aby w ramach polityki rozwoju na okres po 2015 r. uznano niezbywalne prawa kobiet i dziewcząt do nietykalności cielesnej i samodzielnego podejmowania decyzji, między innymi prawo dostępu do dobrowolnego planowania rodziny, bezpiecznej i legalnej aborcji oraz życia bez przemocy, w tym bez okaleczania żeńskich narządów płciowych, małżeństw zawieranych w wieku dziecięcym, wczesnych i przymusowych małżeństw oraz gwałtów małżeńskich" (Opinia, 2014). Kluczowym problemem jest to, że w niektórych krajach aborcja nie jest legalna albo przypadki, w których legalna aborcja jest możliwa, są bardzo ograniczone.

Paradoksalne, ale wymowne stanowisko Rady i jego znaczenie dla międzynarodowej debaty osłabia fakt, że Rada po raz kolejny przywołuje i potwierdza zobowiązania państw członkowskich UE z roku 2000, dotyczące poziomu oficjalnej pomocy rozwojowej (ang. Official Development Aid, dalej: ODA). Dziś już wiadomo, że ODA zdecydowanej większości państw UE nie osiagnie w finalnym roku Milenijnych Celów Rozwojowych obiecanego poziomu 0,7\% dochodu narodowego. W roku 2013 zaledwie cztery państwa członkowskie UE przekroczyły ten pułap: Szwecja, Luksemburg, Dania i Wielka Brytania. Blisko osiągnięcia założonego poziomu jest Holandia $-0,67 \%$ w 2013 r. (Aid Beyond, 2014: 15). Tak słabe wykonanie wcześniejszych obietnic nie jest spójne z zapewnieniem, że współpraca rozwojowa pozostaje „kluczowym priorytetem" UE. Szczególnie jeżeli uświadomimy sobie, że takie państwa jak Bułgaria, Cypr, Polska czy Wegry na ODA przeznaczają 0,1\% dochodu narodowego, a Słowacja, Chorwacja, Łotwa, Rumunia jeszcze mniej (od 0,07 do 0,09\%).

W związku z niskim poziomem ODA państw członkowskich UE, deklaracji Rady w sprawach finansowych nie można uznać za specjalnie wiarygodną. Rada uważa, że podejście do źródeł finansowania walki z ubóstwem powinno być „holistyczne, spójne 
i wszechstronne" (Konkluzje Rady, 2014: 6). Podtrzymuje też znaczenie nadane wcześniej ODA, uznając ją za „ważny i katalityczny element” całego mechanizmu finansowania rozwoju. Jeżeli tak miałoby być w rzeczywiści, to dlaczego zbiorcza ODA Unii Europejskiej w roku 2013 miała poziom zaledwie $0,38 \%$ dochodu narodowego państw członkowskich? (Aid Beyond, 2014: 15). Dziś wiadomo już, że radykalna poprawa tych wskaźników w roku 2014 i 2015 nie jest możliwa.

Parlament Europejski kadencji 2014-2019, postanowił zaktualizować swe stanowisko z 2013 r. i 25 listopada przyją raport, przygotowany przez chorwackiego posła Davora Stiera, ,,w sprawie UE i globalnych ram rozwoju po roku 2015”. Podobnie, jak inne instytucje unijne, Parlament Europejski, jest zwolennikiem podejścia ambitnego. Widać to już w zdaniu wprowadzającym do tej części raportu, która mówi o priorytetach nowej agendy rozwojowej: ,,[... [likwidacja ubóstwa musi pozostać najważniejszym priorytetem globalnego programu działań na rzecz rozwoju po roku 2015, podobnie jak powiązane ze sobą filary stabilności gospodarczej, zrównoważonego rozwoju ekologicznego i zrównoważonego rozwoju społecznego, a także wzmocnione partnerstwo globalne" (Sprawozdanie, 2014: 11). Kwestia ambitnych celów jest wyrażona expressis verbis. Sugerując pewne zmiany Organizacji Narodów Zjednoczonych, Parlament stwierdza, iż „,[...] nie może się to odbyć kosztem podejścia opartego na prawach ani bardziej ambitnych i innowacyjnych celów" (ibidem: 10-11). W przypadku podejścia w oparciu o prawa człowieka Parlament jest jeszcze bardziej zdecydowany $\mathrm{i}$, ,[...] wyraża jednak zaniepokojenie faktem, że do tej pory nie przyjęto bardziej ambitnego podejścia" (ibidem: 12). Posłowie ostrzegli też przed skutkami, jakie niesie dla krajów rozwijających się, liberalizacja handlu. Zaliczono do tych skutków spadek wpływów budżetowych z tytułu handlu, a także ograniczenie siły przetargowej pracowników oraz dumping socjalny i środowiskowy.

W sprawozdaniu ani razu nie padł termin „wolny handel”. Punkt ciężkości jest przesunięty na wspieranie koncepcji ,sprawiedliwego handlu” (ang. fair trade). Parlament zaapelował o to, by dzięki nowym globalnym ramom powstał bardziej sprawiedliwy i zrównoważony system handlu oparty na dialogu, przejrzystości i szacunku i sprzyjający większej równości w handlu międzynarodowym” i uznał potrzebę „by w nowych globalnych ramach promować powszechny, przejrzysty, oparty na zasadach, otwarty, niedyskryminacyjny i sprawiedliwy wielostronny system handlu w ramach WTO" (ibidem: 17-18). Dotychczasową sytuację w zakresie handlu międzynarodowego pośrednio uznano, za niezadowalającą i zaapelowano „o przejrzyste i sprawiedliwe zasady dostępu do rynków lokalnych i międzynarodowych, które dają wszystkim zainteresowanym stronom równe szanse" (ibidem: 18). Jedną z konsekwencji dystansu do liberalizacji handlu jest to, że ocena roli sektora prywatnego w wizji rozwojowej Parlamentu jest ambiwalentna. $Z$ jednej strony posłowie deklarują, że „[...] sektor prywatny powinien być kluczowym motorem trwałego rozwoju gospodarczego sprzyjającego włączeniu społecznemu" (ibidem). Z drugiej jest to obwarowane długą listą warunków trudnych do spełnienia dla sektora prywatnego, który z definicji jest nastawiony na generowanie zysku. Do warunków tych zaliczono: prawa człowieka, prawa pracownicze, rozliczanie przedsiębiorstw, mechanizmy przejrzystości, dialog społeczny, zobowiązania środowiskowe oraz udoskonalenie społecznej odpowiedzialności przedsiębiorstw wielonarodowych za pomocą prawnie wiążących przepisów (ibidem). 
Wstrzemięźliwości Parlamentu wobec „wielkiego” biznesu, towarzyszy wyraźne i jednoznaczne wsparcie dla podmiotów ekonomii społecznej oraz mikro-przedsiębiorstw, a także przedsiębiorstw małych i średnich ${ }^{7}$. Parlament liczył też, że w konkluzjach Rady z grudnia 2014 r. znajdą się „główne założenia strategii negocjacyjnej” (ibidem: 9). To oczekiwanie zostało zrealizowane jedynie połowicznie. Rada określiła wprawdzie założenia, ale są one sformułowane bardzo ogólnie i nie ujawniają tego, jak będzie wyglądała strategia negocjacyjna. Rada zapowiada na przykład, że UE i państwa członkowskie „będą nadal odgrywały aktywną i konstruktywną rolę w nadchodzących procesach i wspierały ich konwergencję w celu osiagnięcia jednej nadrzędnej agendy post 2015" (Konkluzje Rady, 2014: 7). W tym celu UE i państwa członkowskie mają rozwijać i aktualizować wspólne stanowisko. Z kolei celem wspólnego stanowiska jest umożliwienie efektywnego zaangażowania w negocjacje międzyrządowe w sposób jednoczący państwa UE. Rada zapowiada też kontynuowanie współpracy z wszystkim partnerami i zainteresowanymi - społeczeństwem obywatelskim, parlamentami, instytucjami naukowymi i akademickimi, władzami lokalnymi, sektorem prywatnym, partnerami filantropijnymi i społecznymi (ibidem). Rada podkreśla wagę współpracy nad wspólnymi inicjatywami i deklaracjami, podejmowanymi z organizacjami regionalnymi. Ostatnia deklaracja Rady dotyczy jej gotowości do „odegrania aktywnej roli w budowaniu koniecznego konsensusu".

Stanowiska Komisji Europejskiej, Parlamentu Europejskiego i Rady w sprawie przyszłej agendy rozwojowej nie są identyczne, ale można uznać je za kompatybilne i zgodne, co do kluczowego priorytetu, jakim jest dla wszystkich instytucji UE kontynuowanie ograniczania ubóstwa na świecie. Problemem jest stosunkowo niski status UE w ramach prac ONZ nad nową agendą. Podczas szczytu ONZ poświęconego przeglądowi $M D G s$ w Nowym Jorku we wrześniu $2013 \mathrm{r}$. delegacja $\mathrm{UE}^{8}$ siedziała między przedstawicielami Stolicy Apostolskiej i Palestyny. Wśród 18 mówców głównej sesji tego wydarzenia, zaledwie dwóch reprezentowało UE lub państwa członkowskie UE: przewodniczący Komisji Europejskiej José Manuel Barroso i wicepremier Irlandii Eamon Gilmore.

Oficjalnie instytucje UE chciałyby, aby nowa agenda rozwojowa była ambitna i doprowadziła do trwałej transformacji krajów rozwijających się. Można jednak wątpić czy poparcie dla ambitnych celów rozwojowych jest autentyczne i równomiernie rozłożone w państwach członkowskich UE. Wiele państw UE przeznacza na oficjalną pomoc rozwojową bardzo mało funduszy (w porównaniu do składanych deklaracji i obietnic). Ambitna polityka rozwojowa nieuchronnie prowadzi do wyższych kosztów dla państw rozwiniętych. Tymczasem począwszy od początku kryzysu gospodarczego w roku 2008 gotowość większości państw UE do finansowania współpracy rozwojowej zmniejszyła się, a nie zwiększyła.

\footnotetext{
7 Jedną z organizacji pozarządowych promujących ekonomię społeczną w Afryce jest poznańska Fundacja Pomocy Wzajemnej BARKA.

${ }^{8}$ W składzie: José Manuel Barroso, przewodniczący Komisji Europejskiej; Janez Potočnik, komisarz UE ds. Środowiska; oraz autor niniejszego artykułu.
} 


\section{Bibliografia}

Aid Beyond 2015. Europe's role in financing and implementing sustainable development goals post 2015 (2014), [Brussels].

A New Global Partnership: Eradicate Poverty and Transform Economies Through Sustainable Development. The Report of the High-Level Panel of Eminent Persons on the Post-2015 Development Agenda (2013), New York.

Commission guide: EU ready to play 'key role' in post-2015 development framework (2015), "The parliament Magazine", 16.02.2015.

Common African Position (CAP) on the Post-2015 Development Agenda (2014), Addis Ababa.

European Report on Development. Post 2015: Global Action for an Inclusive and Sustainable Future (2013), Brussels.

Fourth EU-Africa Summit, Roadmap 2014-2017 (2-3 April 2014), Brussels.

Godne życie dla wszystkich: eliminacja ubóstwa i zapewnienie światu zrównoważonej przyszłości. Komunikat Komisji Europejskiej (2013), Doc. 7075/13, COM (2013) 92 final.

Godne życie dla wszystkich: od wizji do wspólnego działania. Komunikat KE (2014), Doc. 10412/14, COM (2014) 335 final.

Konkluzje Rady do Spraw Zagranicznych z 12 grudnia 2013 r. w sprawie finansowania eliminacji ubóstwa i zrównoważonego rozwoju po 2015 (2013), Doc. 17553/13.

Konkluzje Rady do Spraw Ogólnych z 16 grudnia 2014 r. w sprawie transformacyjnej agendy po roku 2015 (2014), Doc. 16716/14.

Konkluzje Rady do Spraw Zagranicznych z 19 maja 2014 r. w sprawie podejścia do wspótpracy na rzecz rozwoju, opartego na prawach i obejmujacego wszystkie prawa człowieka (2014b), Doc. 10020/14.

Konkluzje Rady do Spraw Ogólnych z 25 czerwca 2013 r. w sprawie nadrzędnego programu działań na okres po roku 2015 (2013b), Doc. 11559/13.

Mackie J., El Fassi S., Rocca C., Grosse-Puppendahl S. (2013), A Question of Leadership? Challenges for Africa-EU relations in 2014, „ECDPM Policy and Management Insights”, No. 5, Maastricht.

Opinion of the Committee of the Regions - Empowering local authorities in partner countries for enhanced governance and more effective development outcomes (2013/C 356/15).

Opinia Europejskiego Komitetu Ekonomiczno-Społecznego w sprawie: Ustanowienie celów zrównoważonego rozwoju: wkład społeczeństwa obywatelskiego w stanowisko UE (2013), (NAT/594).

Opinia Europejskiego Komitetu Ekonomiczno-Społecznego w sprawie zaangażowania sektora prywatnego w ramy rozwoju na okres po 2015 (2013), (REX/386).

Perspektywy po roku 2015: w stronę wszechstronnego i zintegrowanego podejścia do finansowania eliminacji ubóstwa i do zrównoważonego rozwoju. Komunikat Komisji Europejskiej (2013), Doc. 12434/13, COM (2013) 531 final.

Proposal of the Open Working Group on Sustainable Development Goals (2014), New York.

Putting People and Planet First. CONCORD - Beyond 2015 European Task Force Recommendations for the Post-2015 Framework (2013), Brussels.

Report on the Consultation process on Towards A Post-2015 Development Framework Final Report, (2012), Brussels.

Re-Shaping Global Development: Will Europe Lead? An Argument and a Call to Action. The Independent Vision Group on European Development Cooperation (2014), Brighton. 
Rezolucja ustawodawcza Parlamentu Europejskiego z 2 kwietnia 2014 r. w sprawie wniosku dotyczacego decyzji Parlamentu Europejskiego i Rady w sprawie Europejskiego Roku Rozwoju (2015), COM (2013) 0509 - C7-0229/2013 - 2013/0238 (COD).

Rippin N. (2013), Post 2015: Special Event on Post-2015 - Stuck in the process?, DIE Briefing Paper, No. 19, Bonn.

Sprawozdanie Parlamentu Europejskiego w sprawie milenijnych celów rozwoju-określenie ram po 2015 (2013), 2012/2289 (INI).

Sprawozdanie Parlamentu Europejskiego w sprawie UE i globalnych ram rozwoju po roku 2015 (2014), Brussels, 17.11.2014.

Tomlison J. (1991), Cultural Imperialism: A Critical Introduction, London.

Traktat o funkcjonowaniu Unii Europejskiej (2007), w: Wersje skonsolidowane Traktatu o Unii Europejskiej i Traktatu o funkcjonowaniu Unii Europejskiej. Karta praw podstawowych Unii Europejskiej, (2010), Luksemburg.

Większa rola sektora prywatnego w osiaganiu trwatego wzrostu gospodarczego sprzyjajacego właczeniu społecznemu w krajach rozwijajacych się. Komunikat Komisji Europejskiej (2014), Doc. 9802/14, COM (2014) 263 final.

Zalecenie Parlamentu Europejskiego dla Rady z 11 czerwca 2013 r. w sprawie 68. sesji Zgromadzenia Ogólnego Organizacji Narodów Zjednoczonych (2013), 2013/2034 (INI).

Zalecenie Parlamentu Europejskiego dla Rady z 2 kwietnia 2014 r. w sprawie 69. sesji Zgromadzenia Ogólnego Organizacji Narodów Zjednoczonych (2014), 2014/2017 (INI).

\title{
STRESZCZENIE
}

Ważność aktualnej, globalnej agendy rozwojowej, znanej pod nazwą Milenijne Cele Rozwojowe (MDGs), kończy się 31 grudnia 2015 r. Od 2010 r. trwają prace analityczne, programowe i polityczne nad nową agendą rozwojową, która zastąpi MDGs począwszy od 1 stycznia $2016 \mathrm{r}$. Unia Europejska jest bardzo aktywnym uczestnikiem prac nad kształtem kolejnej agendy rozwojowej. Aktywność UE w tym obszarze wynika zarówno z ambicji tej organizacji, chcącej odgrywać rolę „globalnego gracza”, jak i znaczenia założeń globalnej polityki rozwojowej dla unijnej współpracy rozwojowej. Nieprzypadkowo Unia Europejska ogłosiła rok 2015 Europejskim Rokiem na rzecz Rozwoju - European Year for Development (EYD). Artykuł przedstawia stanowisko najważniejszych instytucji UE wobec nowej agendy rozwojowej (Post 2015).

\section{EU POSITION ON THE POST 2015 DEVELOPMENT AGENDA}

\begin{abstract}
The validity of the current global development agenda, known as the Millennium Development Goals (MDGs) ends on December 31, 2015. International community has worked on the new development agenda since 2010. The new development agenda will replace the MDGs from 1 January 2016. The European Union is a very active participant in the work on the shape of the new development agenda. EU activity in this area is coming clearly both from the organization's ambition, wanting to play the role of a ,global player" and the importance of global development policy objectives for the EU's development cooperation. Not coincidentally, the European Union announced the 2015 European Year of Development (EYD). The article presents the position of the most important institutions of the EU towards a new agenda for development (Post 2015 agenda).
\end{abstract}

